\title{
DIFFERENCES IN CHANGES OF HEMOGLOBIN BETWEEN 6-12 HOURS AND 12-14 HOURS AFTER TRANSFUSION
}

\author{
Rosita Linda, Devita Ninda \\ Department of Clinical Pathology, Faculty of Medicine, University Islam Indonesia,Yogyakarta, Indonesia. E-mail: \\ linda.rosita@uii.ac.id
}

\section{ABSTRACT}

Each year more than 41,000 blood donations are needed every day and 30 million blood components are transfused. Blood products that can be transfused include Packed Red Cells (PRC), Whole Blood (WB), Thrombocyte Concentrate (TC), Fresh Frozen Plasma (FFP). Monitoring Hemoglobin ( $\mathrm{Hb}$ ) after transfusion is essential for assessing the success of a transfusion. The time factor after transfusion for Hemoglobin ( $\mathrm{Hb})$ examination needs to be established, analyze to judge the success of a blood transfusion which is performed. The aim of this study was to analyze the differences in changes of hemoglobin between 6-12 hours, and 12-24 hours after-transfusion. This study was retrospective observational using secondary data. The subjects were patients who received PRC, and WBC transfusion. At 6-12, and 12-24 hours after-transfusion, hemoglobin, $\mathrm{RBC}$, and hematocrit were measured. Then the data were analyzed by unpaired t-test. The collected data included the results of the $\mathrm{Hb}$ pre-transfusion, 6-12, and 12-24 hours after-transfusion. The subjects of this study were 98 people. The administration of transfusion increased by $10-30 \%$ in hemoglobin concentration at 6-12 hours after-transfusion. While at 12-24 hours after-transfusion, hemoglobin after-transfusion increased $15-37 \%$ from the baseline. Hemoglobin values were not different at any of the defined after-transfusion times $(p=0.76(p>0.05))$. Hemoglobin values were not different at 6-12 hours, and 12-24 hours after-transfusion. Keywords: Hemoglobin, measurement, after-transfusion

Key Words: Hemoglobin, measurement, after-transfusion

\section{INTRODUCTION}

Each year the need for blood is increasing. In the United States, every two seconds, there is one person who needs blood. More than 41,000 blood donations are needed every day, and 30 million blood components are transfused each years.1 The aftertransfusion, Hemoglobin $(\mathrm{Hb})$ monitoring is essential to be done in assessing the success of a transfusion. The time factor of aftertransfusion $\mathrm{Hb}$ examination needs to be established, to judge the success of a blood transfusion which is performed. The main purpose of blood transfusion is to save lives, and improve health status. Some people require blood transfusions for surgery, accidents, disasters that cause loss of blood. Others require blood for diseases such as severe infection or liver disease that could interfere with the process of the formation of a blood disease that causes anemia such as kidney disease or cancer, blood disorders, and diseases such as hemophilia.2 A wide variety of products that can be transfused as blood components, include Packed Red Cells (PRC),
Whole Blood (WB), Thrombocyte Concentrate (TC), Fresh Frozen Plasma (FFP). Whole Blood (WB) is a fluid assortment of blood cells which are joined in a yellowish liquid called plasma. Packed red cells are derived from the WB that most of the plasma has been reduced. Platelets are blood components that concentrate its main content in platelets. Fresh frozen plasma is plasma frozen within 8 hours after collection. Among the components of the blood, the most widely used technique to raise hemoglobin is PRC. ${ }^{3}$

Packed reds cells are transfused in patients who indicate anemia, and bleeding. Acute hemorrhage with a loss of more than $15 \%$ of blood volume should immediately get a transfusion. Pre-operative patients with $\mathrm{Hb}<9.0 \mathrm{~g} / \mathrm{dL}$ who have the possibility of blood loss $>500 \mathrm{~mL}$ during surgery also require blood transfusions. Patients with $\mathrm{Hb}<7.0 \mathrm{~g} / \mathrm{dL}$ with severe pain, $\mathrm{Hb}$ $<8.0 \mathrm{~g} / \mathrm{dL}$ with acute coronary syndromes, $\mathrm{Hb}<10.0 \mathrm{~g} /$ $\mathrm{dL}$ with uremia or bleeding due to thrombocytopenia require blood transfusions. Also, patients with sickle cell disease, need routine blood transfusions. ${ }^{4}$ 
Packed red cells transfusion can increase blood hemoglobin, and hematocrit. One unit of PRC will raise hemoglobin in adults by an average of $1 \mathrm{~g} /$ $\mathrm{dL}$, and raise the hematocrit by $3 \%,{ }^{5}$ but the theory does not provide for a limitation of the volume of the unit. As it is known that the volume of each bag does not provide for a limitation of the volume of the unit. As it is known that the volume of each bag does not contain the same PRC. Packed red cells volume average is between $250-300 \mathrm{~mL}$ for regular bags while for pediatric packs the average is $50-60 \mathrm{~mL}$. According to a study Elzik et al., ${ }^{7}$ PRC transfusion can increase the hematocrit value was $6.4 \% \pm 4.1 \%$ per liter of blood transfused. In other words, the hematocrit will increase by $1.9 \% \pm 1.2 \%$ per $300 \mathrm{~mL}$ of blood transfused. ${ }^{6}$

Some study suggests the interval after transfusion hemoglobin affects the increase in the value of hemoglobin. According to Wakhidah et al, increased levels of hemoglobin occur at 6 hours aftertransfusion examination, and then declined in the examination 12 hours. This study aimed to assess whether there are differences in $\mathrm{Hb}$ levels 6-12 hours after-transfusion with 12-24 hours after-transfusion. ${ }^{7}$

\section{METHODS}

A retrospective observational study was conducted using $\mathrm{Hb}$ data examination results in the pre, and after-transfusion. The location of the study was in the JIH Hospital. Subjects were patients who received PRC transfusions, and WBC of all diagnosis. Inclusion criteria for this study is a subject that has a complete data of better examination results of pre, and after $\mathrm{Hb}$. Laboratory tests include routine blood tests (hemoglobin, RBC, and HCT). Operational definitions of the variables used are pre-transfusion $\mathrm{Hb}$ inspection; criteria are $\mathrm{Hb}$ examination conducted before transfusion, which is an indication of doctors doing a transfusion. While the criteria for $\mathrm{Hb}$ after-transfusion examination is an examination conducted after $\mathrm{Hb}$ transfusion, which is divided into two groups: 6-12 hours, and 12-24 hours after-transfusions.

\section{RESULT AND DISCUSSION}

There were 98 people as study subjects, who met the inclusion criteria of patients getting PRC transfusions, and WB of all disease diagnosis and who had complete better data on before, and after $\mathrm{Hb}$ examination results. Laboratory tests included routine blood tests (hemoglobin, RBC, and HCT).

The study subjects were divided into four groups: blood groups $A, B, A B$, and $O$. While the study subjects were restricted from patients who received $P R C, W B$, and obtained both (PRC, and WB transfusions).

Most blood type A were as much as $30 \%$. Blood type B by $28 \%$. As many as $16 \%$ of study subjects had blood type $A B$, and the remaining $26 \%$ were blood group $O$. The characteristics of the study subjects can be seen in Table 1, Figure 1, and Figure 2.

In this study, it showed the variation of all blood types requested, because there was no dominant demand for one type of blood groups. However, the group A which is indeed the most widely in population, also showed a demand more than other blood types.

Table 1. Baseline data

\begin{tabular}{lcl}
\hline Characteristics & Number & $\%$ \\
\hline Blood type & 29 & 30 \\
A & 27 & 28 \\
B & 16 & 16 \\
AB & 26 & 26 \\
O & & \\
Type of component & 77 & \\
PRC & 11 & \\
WB & 69 & \\
PRC, and WB &
\end{tabular}

The highest of $\mathrm{Hb}$ subject in group A was 12.3 $\mathrm{g} / \mathrm{dL}$ and the lowest $5.3 \mathrm{~g} / \mathrm{dL}$. While the highest of $\mathrm{Hb}$ subjects in group $B$ was $11.2 \mathrm{~g} / \mathrm{dL}$, and the lowest was $6.7 \mathrm{~g} / \mathrm{dL}$, in the $A B$ group was $12.3 \mathrm{~g} / \mathrm{dL}$ and 1.8 $\mathrm{g} / \mathrm{dL}$, and in the $O$ group is $10.5 \mathrm{~g} / \mathrm{dL}$, and $1.8 \mathrm{~g} / \mathrm{dL}$.

In this study, it showed that an increase in hemoglobin ranged from 6-12 hours after-transfusion $10-30 \%$ of its original value, while the increase in $\mathrm{Hb}$ at $12-24$ hours after-transfusion was ranged $15-37 \%$ of the original value of $\mathrm{Hb}$. From the test results, it was shown that the value of t-test $p=0.76(p>0.05)$.

From Table 5 , it showed that there was no difference in $\mathrm{Hb}$ levels examined between 6-12 hours after-transfusion, and 12-24 hours aftertransfusion, meaning clinicians sufficiently examined changes in hemoglobin levels over the span of 24 hours, either choosing 6-12 hours after-transfusion, and 12-24 hours after-transfusion. Rapid time to ass- 
ess the success of transfusion was also an important part of choosing the right time for the second time.

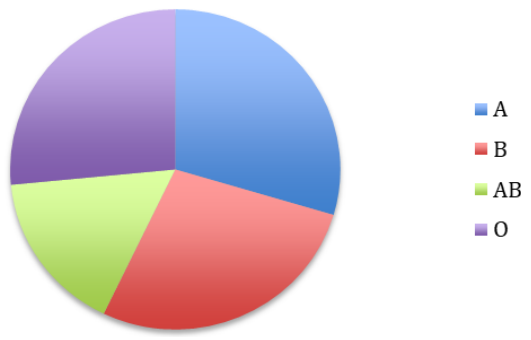

Figure 1. Distribution of blood

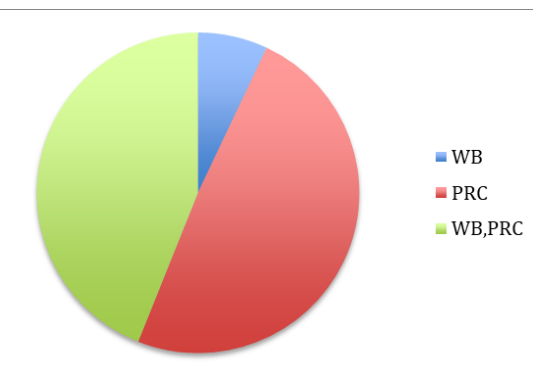

Figure 2. Distribution of blood transfusion components

These results were similar to the study conducted by Elizalde et al., ${ }^{8}$ who stated that the result of the current $\mathrm{Hb}$ at 15 minutes, and 24 hours aftertransfusion was not significantly different. Only $6 \%$ of patients had significant differences from the measured hemoglobin concentration (over 6\%).

Weisen et al., ${ }^{9}$ also showed the same findings. The mean increase in hemoglobin of $20 \mathrm{~g} / \mathrm{L}$ $(95 \% \mathrm{Cl}, 17$ to $22 \mathrm{~g} / \mathrm{L})$ for 24 hours after-transfusion of 2 units of PRC. Hemoglobin levels before transfusion were lower compared to after ( $P$ $<0.001$ ), but there was no significant difference in the measurement at 15 minutes, 1 hour, 2 hours, and 24 hours after-transfusion ( $P=0.82)$. Changes in hemoglobin concentration between 15 minutes, and 24 hours after-transfusion ranged from $20 \mathrm{~g} / \mathrm{L}$ aftertransfusion of 2 units of PRC $(-2.2 \mathrm{~g} / \mathrm{dL}$ to $2.0 \mathrm{~g} / \mathrm{dL}) .{ }^{9}$

The study conducted by Audu et al., ${ }^{10}$ in neonates without bleeding indicated the right time to perform measurements of hematocrit aftertransfusion in children whose condition are stable, no active bleeding, and without hemolysis condition in 12 hours after-transfusion. The measurement results in hematocrit 1 hour, and 6 hours aftertransfusion indicated that there was no difference $(47.8 \% \pm 5.6 \%)$. But these results differed significantly with measurements at the 12 hours to 24, and 48 after-transfusion The difference variated between $1.3 \%$ to $3.5 \%(0.4 \mathrm{~g} / \mathrm{dL}$ to $0.9 \mathrm{~g} / \mathrm{dL})$. The mean after-transfusion of hematocrit at 1 , and 12 hours differed significantly from the target. While measurements at the 12 hours to 24 , and 48 hours were in accordance with the hematocrit target of after -transfusion. ${ }^{10}$

Table 2. Comparison of increased $\mathrm{Hb}$ between 6-12 hours, and 12-24 hours after-transfusion

\begin{tabular}{lcc}
\hline & After-transfusion & After-transfusion \\
\cline { 2 - 3 } & $\mathbf{6 - 1 2}$ hours & $\mathbf{1 2 - 2 4}$ hours \\
\hline A & 2.6 & 3 \\
B & 1.1 & 1.2 \\
AB & 0.3 & 0.5 \\
O & 1.7 & 2.1 \\
\hline
\end{tabular}

Another study conducted by Hoque et al., ${ }^{11}$ demonstrated $\mathrm{Hb}$ at 24 hours after-transfusion, rose more than $1 \mathrm{~g} / \mathrm{dL}$ in patients without active bleeding. Hoque et al., ${ }^{11}$ also stated there was a significant difference in hemoglobin in the examination at 24 hours after-transfusion. Comparison of the $\mathrm{Hb}^{\prime}$ 's mean before, and 6 hours after-transfusion was statistically significant. Comparison between $\mathrm{Hb}$ before, and 24 hours after-transfusion also differed significantly. $\mathrm{Hb}$ at 6 hours $(8: 03 \mathrm{~g} / \mathrm{dL})$ compared to 24 hours $(8.78 \mathrm{~g} / \mathrm{dL})$ was significantly different. ${ }^{11}$

The difference is most probably due to the inclusion different criteria of study subjects. In a study by Hoque et al. $^{11}{ }^{11}$, the study subjects were patients with no active bleeding, and the clinical condition was stable. ${ }^{11}$ While in this study all patients who received transfusions PRC, WB, or both were included as the study subjects.

Packed red cells were transfused in patients who had an indication of anemia, and bleeding. Acute hemorrhage with loss of more than $15 \%$ of blood volume should immediately receive a transfusion. Preoperative patients with $\mathrm{Hb}<9.0 \mathrm{~g} / \mathrm{dL}$ who had the possibility of blood loss $>500 \mathrm{~mL}$ during surgery also required blood transfusions. Patients with $\mathrm{Hb}<7.0 \mathrm{~g} / \mathrm{dL}$ with severe pain, $\mathrm{Hb}<8.0 \mathrm{~g} / \mathrm{dL}$ with acute coronary syndromes, $\mathrm{Hb}<10.0 \mathrm{~g} / \mathrm{dL}$ with uremia or bleeding due to thrombocytopenia required blood transfusions. In addition, patients with sickle cell disease need regular blood transfusions. ${ }^{4}$

Packed red cells transfusion can increase blood haemoglobin, and hematocrit. One unit of PRC will raise the hemoglobin in adults at an average of $1 \mathrm{~g} / \mathrm{dL}$, and hematocrit increased by $3 \%$. In children transfu- 
sions as much as $5 \mathrm{~mL} / \mathrm{kgBW}$ would raise the hemoglobin concentration at $1 \mathrm{~g} / \mathrm{dL}^{5}$

But the theory does not provide for a limitation of the volume of the unit. As it is known that the volume of each PRC bag is not the same. Packed red cells volume averaged between $250-300 \mathrm{~mL}$ for regular bags for pediatric pack while the average is of 50 $60 \mathrm{~mL}$. According to a study by Elzik et al., ${ }^{6}$ PRC transfusion can increase the hematocrit value was $6.4 \% \pm 4.1 \%$ per liter of blood transfused. In other words, the hematocrit will increase by $1.9 \% \pm 1.2 \%$ per $300 \mathrm{~mL}$ of blood transfused. ${ }^{6}$

Patient characteristics such as age, weight, body surface area, estimated blood loss, a history of heart failure, the use of diuretics, creatine with a clearance less than $30 \mathrm{~mL} / \mathrm{min}$, the duration between transfusions, history of fever is said not to affect the rise in hemoglobin levels. Correlation level at 24 hours after-transfusion hemoglobin with age, the volume of blood transfusion, and transfusion time was not statistically significant. ${ }^{9}$

A study conducted by Naidech et al., ${ }^{12}$ in patients with subarachnoid hemorrhage with anemia showed a lower pre-transfusion hemoglobin concentration correlated with the increase in aftertransfusion hemoglobin level. In a retrospective cohort data group, and a prospective cohort obtained pre-transfusion hemoglobin levels associated with elevated levels of hemoglobin $(P<0.001)$ aftertransfusion of a single unit of PRC. ${ }^{12}$

In some cases, $\mathrm{Hb}$ after-transfusion showed increase not as much as expected. Conditions that cause the loss, sequestration, or the destruction of red cells should be sought. Examples of these conditions such as vague bleeding, repeated blood sampling (especially in children), fever, hypersplenism, primary, and secondary causes of immunology, some type of hemolysis or mechanical problems. ${ }^{13}$

Other conditions that may affect the type of PRC is given. The new PRC that is stored up to 5 days. In the new PRC, erythrocyte hemolysis in storage cannot circulate once transfused. This means that the red cells cannot function in the process of oxygen delivery, capturing carbon dioxide, and other functions of erythrocytes. Besides, there was an increase in 2-3DPG so that the oxygen dissociation curve changed. ${ }^{14}$

\section{CONCLUSION AND SUGGESTION}

There was no significant difference in $\mathrm{Hb}$ moni- oring between at 6-12 hours, and 12-24 hours aftertransfusion. Level of $\mathrm{Hb}$ after-transfusion could be measured after 6-12 hours transfusion.

\section{REFERENCES}

1. The American National Red Cross, 2013 Annual Report, Accessed at $7^{\text {th }}$ July 2017, www.redcross.org// m39440096_2013AnnualReport.pdf.

2. US Department of Health \& Survey System, National Blood Collection, and Utilization Survey Report. 2012; 2-3, Accessed at $7^{\text {th }}$ July 2017, https://www.aabb.org/ bloodsurvey/11-nbcus-report.pdf.

3. Departemen Kesehatan Republik Indonesia. Modul 2 Pelatihan Crash Program Petugas Teknis Transfusi Darah Bagi Petugas UTDRS, Jakarta, Departemen Kesehatan Republik Indonesia, 2008; 7-10.

4. Kiswari R. Hematologi \& Transfusi, Jakarta, Erlangga Medical Series, 2014; 50-70.

5. American Society of Hematology. Clinical Practice on Red Blood Cell Transfusion, 2012; 1-4.

6. Elzik ME, Dirschl RD, Dahners LE. Correlation of Transfusion Volume to Change in Hematocrit, American Journal of Hematology, 2006; 81(2):145-146.

7. Wakhidah. Evaluasi Waktu Pemeriksaan Kadar Hemoglobin Sesudah Transfusi Darah pada Pasien Anemia di Rumah Sakit Islam Kendal, Skripsi, D4 Analis, Unimus, 2013; 13-15.

8. Elizalde JI, Clemente J, Marín JL, Panés J, Aragón B, Mas A, Piqué JM, Terés J. Early Changes in Hemoglobin and Hematocrit Levels after Packed Red Cell Transfusion in Patients with Acute Anemia, Transfusion 1997; 37(6): 573 $-576$.

9. Wiesen AR, Hospenthal DR, Byrd JC, Glass KL, Howard RS, Diehl LF. Equilibration of Hemoglobin Concentration after Transfusion in Medical Inpatients Not Actively Bleeding, Ann Intern Med. 1994; 121(4): 278-280.

10. Audu LI, Otuneye AT, Mairami AB, Mshelia LJ, Nwatah VE. After Transfusion Hematocrit Equilibration: Timing After Transfusion Hematocrit Check in Neonates at the National Hospital, Abuja, Nigeria, International Journal of Pediatrics, 2015; 2015(2015): 1-5.

11. Hoque MM, Adnan SD, Karim S, Al Mamun MA, Nandy S, Faruki MA, Mahmud K, Islam K. Equilibration and Increase of Hemoglobin Concentration after One Unit Whole Blood Transfusion Among Patients Not Actively Bleeding, Journal of Dhaka Medical College 2014; 23(2): 161-166.

12. Naidech AM, Kahn MJ, Soong W, Green D, Batjer H, Bleck TP. Packed Red Blood Cell Transfusion Causes Greater Hemoglobin Rise at a Lower Starting Hemoglobin in Patients with Subarachnoid Hemorrhage, Neurocrit Care 2008; 9(2): 198-203.

13. Liumbruno G, Bennardello F, Lattanzio A, Piccolo P, Rossetti $G$. Recommendations for the transfusion of red blood cells, Blood Transfus 2009; 7(1): 49-64.

14. Zimring JC. Fresh versus old blood: are there differences and do they matter? ASH Education Book, 2013; 2013(1): 651-655. 